原著

\title{
複雑特瘻殊に深部広域複雑痔瘦に対する 桩大特瘦根治手術
}

一てとれらの根治手術としての Partial Resection を批判して——

\author{
三枝肛門科 \\ 三 枝 純 郎
}

侍瘦はたとえそれが如何に複雑かつ深部広域に及ぶものであっても, その根治手術に失敗し, その再発を みる事は肚門外科医にとつて，これ以上の恥辱はなく，又著者はその屈辱に注到底耐えられない。

\section{I. 深部広域複雑痔瘦}

在来, と汃く深部広域複雑痔熡に関して, 一体どの様 にすれば $100 \%$ 確実な治洆が得られるのか, 確固たる手 術方法は記載されていない，総じて，この種の症例の手 術に際しての注意事項としては外肛門括約筋を切除すれ ばば失禁を残すという点のみが強調され，それでは外肛 括約筋を切離しなければ, 瘦管〜肉芽組織の完全な摘出 〜切除が不能の場合には一体どうしたら良いのか.この 点に関する確たる説明はなく, どの成書をみても, 洋 書，邦書を問わず，事がこの点に及ぶと，その記述注次 第にアイマイ，モコとなり，正に霧の中にかすんでいる かの如き感を受けるのが普通である14).

以上の点をつきつめて考えていくと，これは在来深部 広域複雑将樭の完全治痹が如何にむずかしく，困難であ ったかを如実に示すものである。

1）拡大淸瘦根治手術（肚門全切除術～严全切除術) 常識的に考えれば，肛門括約筋をその内外に亘って， その大部分又は全部を切除すれば，当然の帰結として， 必ずや年中所謂“タレ流し”の如き完全な失禁状態を招 来するものと解され，又，解され易いのは全く無理から ぬ事であり，単に一般の外科医の方々のみでなく，肛門 外科の専門医の方々も，大部分は恐らく同様に考えてお られる事と思う。

在来の多くの肛門外科成書を探ってみても，この点に 関しては全く，異口同音に失禁を招来すると述べてあ る。而し作らこの見解は必ずしも当を得たものではな く，事柄を余りにも皮相的に又弾純に解しすぎるもの であり，以下の如き場合には，たとえ肛門括約筋をその
内外に亘り，肛問全周に亘って切除するも，さほどの失 禁状態を招来するものではなく，又排便にとり立てて言 うべき障害を残さず，事実柱全くこれと相反する。

即ち深部広域複雑痔瘦, つまり瘅瘦の病巣が甚だ哚く に存在し，更にこれが肛門の全周又はそれに近い状態に 及んで存在す磜には，病宩を含めて肛門をその全周又 は殆ど全周に亘って切除寸るも，その手術が肛門手術原 則に合致するものである限り，即ち病巣を含めてこれ を且状 Saucerized に切除し（むしろ摺り錸状といった 方が良い)一病单を切除した後，更にその周辺を切り整 えて，糞便物質の流れ易い，又これ教貯溜する事のない 良い形の開放創とする一加えてこの開放創が上皮化し治 療に赴く迄の間のその管理，必要に応じての開放創の整 形, 過剩肉芽の切除, 及び街後狭窄防止の為の後方切開 Retroincision，並びに開放創完全上為化後の After care が満足に行なわれる限り，たとえ肚門括約筋をそ の内外全周に亘って切除するも，さほどの障害を残さず これを治瘾せしめる事が出来る。

この様な手術方法を行なら限り，例えば肛門括約能群 をメス等に完全に切断した際に招来されるきき完全失禁 状態はマズ起らない，又この様な拡大痔㿉根治手術は勿 諭好んで行なわれるものではなく，全く止むを得ず行な われるものであり，又その必要な症例は稀で，殊に肍門 全切除術の実施を必要とする症例は，著者の経験を以て しても，甚だ稀である。(この.5 年閒に肛門全切錠術実施 例は 3 例のみ，大体将瘦170例の中にI例ぐら々割合). 又その满足な実施は技術的にも肉体的にも仲々大変な事 で，甚だ面倒な手数及び努力に加えて，特に根気を必要 とし，更にこれがこれが長期に亘るので，これを行なら 
医師の精神的負担はむしろ苦痛に近い，又同時に患者の 長期に亘る充分な協力を必要とし，(郝後 5 年間 は経過 を観察する必要がある)。これらの両者が相俟って初め て満足な成果を収めらるものであり甘く考えて行なら心゙ きものではない。

而し乍ら肛門全周に亘る，又これに近い状熊にある梁 部広域複雑痔瘦に対しては,その完全なつまり $100 \%$ の治 療を求める限り，この種の方法に依る外はなく，著者は この種の痔㿉に対してはこの手術方法が最も完壁に近い ものであると考えている。

著者㚈かより，亡父，三枝俊雄の指導の下，この種 の手術にはげみ，更に著者なりにその方法に改良を加え 現在に及んでいるが，近来溸くこれらの難症側におい て，その大部分をさしたる障碍を残さず根治手術を実施 しうる些かの自信を得るに至った。な抗この手術方法の 詳細及び After care に関しては次回にこれを詳述した いものと考えている15.

2) 肚門括約筋に関する先入観(AnaI Continence を 保つ要因とは)

とかく一般には肛門括約筋の括約筋たる語に惑わされ る余りこれを切除〜離断すれば必す完全な失禁状態を 起すものと信じ込んでいるが，实際には必らずしもそう とは限らない。

Anal continence ${ }^{233)}$ は在来これを Reservoir continence（結腸予潇能力）と Sphincter continence に二 大別して考えられており，後者の要因として種々のもの が唱えられているが，著者はその主因として，Puborectal sling の Tonus 及びそれに由来する直腸と肛門の 為す角度の二者を考えている. 又内肛門括約筋には殆ど 括約筋としての作用はなく，外肛門括約筋も Sphincter continence を保つ最も重要な因子たりえないと考えて いる.

外肛門括約筋が Sphincter Continence の主因たり えない事の証樾として以下をあげる事ができる.

\section{A）深部広域複雑痔度における Rigid Anus}

深部広域複和作疰瘦にあっては既に術前に外肛門括約筋 は炎症の再三の進大により，䬺痕化し，又硬化し，この 種の症例の肛門指診に際して, 所謂 Rigid Anus の状 態を呈し，意識的に肚門をしめる事ができず，即ち外 肚門括約笳は殆どその機能を失っているにも拘らず，

Anal continence は良好である。この事は明白に外肛門 括約筋が Sphincter Continence の要因たりえない事を 示している.

この種の考えは既に古くからあるもので，十余年前に R. J. Jackman は彼の著書の中で次の如く述べてい $る^{1)}$. 即ち内肚門括約筋は実際には殆ど括約筋としての
作用をむたず，又肚門が失禁を起さないでいられるの は外肛門括約筋の強直性レン縮によるものであると言う 考えは誤りである．外肛閏括約笳は平常は閉鍞された状 態にあるとは言うものの，決して完全な収縮状態にある ものではない，実際にやって子机ば分る事であるが，外 肛門括約筇を持続的に収縮させておく事は不可能であっ て，最大限にこれを収縮させ招㚈る時閒は僅加数秒てい どである。

B）著者の肛門全切除例が予想されるほどの障害を残 さない事

外肛門括約筋は上記の如く Sphineter continence の 最も重要な因子たりえないと言っても，あるていどの役 目を果たしている事は否定できない，従つて外肛門括約 筋を全部切除して，全く機能障害を残さないといらのほ 嘘になる。而し乍ら上記の如き方法で手術を行なう限 り，一般に信ぜられる〜想定されるほどの障害を残寸も のではない.

勿論，糞便が過度に軟化せる場合には，殊に水様便に なった場合には，これをこらえる事殆んど不可能である し(正常の者でも往々して不可能であるが)，又粘液の漏 出する所謂 Leakage も時折認められる。而し乍らこれ らはすべて，何等の内科的手段によって防止しらるもの である. 即ち前者にあっては前回詳述しだ算便軟化法 と反対の方法をとる事によって，これを回避する事が出 来るのが普通であるし，粘液の Leakage に対してはプ ロバンサインの必要がに応じての内服が有効であり，必 要とあれば,Jackman の著者に述べられている排便後の 直腸のIrrigation む良い手段であり ${ }^{1}$ ．（著者は未だそ の実施を必要とした症例を経験した事はないが)，粘液 の漏出はあるとしても，総して排便 1 時間以内ていどに 少量の粘液の排出をみるのが普通でこの点を承知して， 患者が生活の調整を計れば（朝食の時間を早めて出勤迄 にゅとりをもたせる)，さして障害を来さない事が多 く，何か特別の事情がある時に Probanthaine を内服す るに留るのが普通である、又著者はこれ迄この種の症例

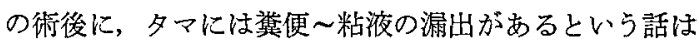
聞くものの，この種の現象に患者が悩まされるとか，又 その治療に手こつっったという症例は，未だ 1 例を経験が ない.

抎大痔瘦根治手術に際して大切な事は，余り扮尻の穴 を大きく又小さく治しすぎない事である、著者の経験で は小指の根元ほどの太さ〜人差指の先が入るていどの太 さが適当である。これ以上に余り太くすると漏れ易い し，余りせまいものも困る，又手術後何日かたって脱出 して来る直腸粘膜は必要に灾して何回かこれを取り除く 必要がある。これをそのままにしでくと，ダブダブの 
大きすぎるお尻の穴になるのみならず，年中心゙トベトの 始末に負えないむのになる由である(三枝俊雄)，これら の点については改めて詳述する予定である.

拡大将瘦根治手術の後に脱出して来る直腸粘膜を上手 に結紮壊死脱落せしめると入口の部分はダ円形の良い形 となり，その奥の直腸粘膜は中心に向って周りから寄っ て来る様な形になり，そこに蓝をするといったら良い か，弁が出来ると言ったら良いか，とに角立ち上ると粘 膜の重みで，そこが閉鎖される様に思われる。

以上の如き理由からか，とに角意外に粘液の漏出は少 なく，少なくとも生活に支障を来す様な事はない，又そ の様に治してやら齐ばならないが，仲々気を使う事夥だ しく, 到底安直には引受けられない.

この種の症例の術後にあつては, 総じて所請 Soft formed stool が適当にて, 糞便がこの種のもので, 又 排便調整が上手に行なわれている限り ${ }^{12}$, 殆ど日常生活 に支障を来すものではない，汃くの如く，肛門全切除術 が一般に信しられているほどの障害を残すむのでない事 は，外肛門括約筋が Spincter continence の最も主要 な因子たりえない事を如実に示すものであるう。

付）お尻の究をすぼめるのは単に外肛門括約筋のみの 作用によるものではない

肛門全切除例の患者は, 術後, その開搬㓱が完全に上 皮化し，その後暫らくすると，あるていど迄便むこらえ られるし，又お尻の穴をすぼめる事も可能となる. 要す るに肛門をすぼめる力は単に外肛門括約筋のみの力によ るものでなく，その他，大慰筋群等の力も大きく関与し てるものの如く解される。この点は当然の事乍ら手術創 曒痕が軟化すればする结ど，良い具合となる。

な拉，肛門の開放性手術はその手術例の単なる完全な 上皮化を以つて治痖とすべきでなくその満足な軟化を以 て治痖とすべきものでありここれが為には相当長期（3 〜 年) に亘る経過の钼察を必要とするものである.

C) 人類のみに認められる外肛門括約筋の異常かつ高 度の発達, 縦長のスリットを示す肛門一その他の 哺乳類の肛門との比較

総して人類の肛門の外肛門括約筋筋の構成をみるにそ の他の哺乳類のそれに比して,正にコレデもが,コレデも か，と言った所が見受けられる。 その由来する所はやは り，人類特有の排便の意識的抑制によるものと思われ る. その他の哺乳類では外肚門括約笳は人類に抢けるほ ど発達していない，この点は個体発生は系統発生をくり 返すと言う大原則より乳児の肛門にも認められよう。而 乙乍ら人類以外の哺乳類でも乳児でも Anal continence は良好である.こうした点より考えると, やはり 外肛門括約は Sphincter Continence の最も重要なる
因子たりえないと言いえよう。

又, 人閒の肛門のみが綎長のスリットとを示す事は，そ 直立生活に由来する所もある事乍ら，その特有な排便の 意識的抑制に由来して，外肛門括約筋が異常に発達した 事に大きく関係しているのではあるまいかか. 又その 他の哺乳類に抒いて肚門が横のスリットを示す事注; Puborectal sling が Sphincter continence の主体を為 寸事の証明ではないであろうか。人類でむ，これほど異 常かつ高度に排便の社会拘束が要求されていなければ, 加えて直立生活に移行していなければ，肛門の形には Puborectal sling の力が最む強く表れ，他の哺乳類同 様肛門は横のスリットを示しているのではなからうかと 思5。

\section{6）深部広域複雑痔瘦の定義}

著者がここで用いている媣部広域複雑痔瘦たる語はそ の正確な定義は困難であるが，要するに上記の複雑侍瘦 の最むひどいものと解して頂いて一向に差支えない，在

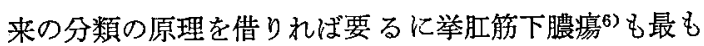
ひどいものと言って良い，言葉をかえれば坐骨直晹窝膿 瘍の広汎にひろがり，外肛門括約筋の中，Levatorani

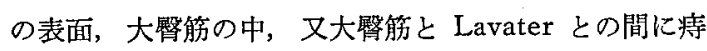
掼組織の侵入したものという。

な和挙肛筋上膿癔即ち Pelvirectal Abscess は成書に 記されているものの実際には滅多にあるものではなく， 著者む未だに幸か不幸か確実な本症例に出会った経験は ない，尤も以前不適当な手術操作により Levater ani を破って (人為的に) 作ってしまった様な例は見た経験 があるか，これは到逶本来の Pelvirectal abscess とは 称しえないであるう。

又痔瘦〜その肉芽組織が，直腸粘膜下，時には内括筋 とPuborectal sling との間を通って, 直腸粘膜下に進 み，時としてそこに abscess を作っているものがあり， これが指の届かない様な所に迄進んでいる事はある，而 しこれを Supra levator abscess と称して良いのか， 甚だ疑問であり，著者は近来挙肛筋上膿瘍と称すべきも のでないと思っている.この種のものも，マズ大部分は 完全な切除〜摘出可能である。この種の手術方法につい ても何れ時を改めて述べたいと考えている.

な抢乳児痔瘦は総して一般に単純かつ表在性のもので あり，複雑痔瘦は存在しないかの如く解されている傾向 が瞀われるが，たとえ乳児痔瘦にあっっても何本かに枝 分れした複雑痔嫂は往々にして存在し，稀ではあるが, 哚部広域複雑侍瘦に準ずると見做すべき症例も事実存在 する。乳児痔瘦ついでも改めて述る7 . 


\section{Partial resection に対する反論}

近来複雑将瘦に対する手術として, その原発孔たる Anal crypt の処理のみで充分であるとか，これに加え て主要瘻管の切開々放を行なえば，それ以上の事，即ち 完全な痔瘦組織の切除を行なわずとも充分であるとの考 え方がある8 .これ即ち明白な Partial resectionの概 念であると言って良い，要するに敢て痔瘦組織をとり残 几て迄も，又それを充分に承知の上で，何とか肛門括約 筋の損傷を防ぎ，その機能を温存せしめたいとの考え方 である．この考え方は誠に結構であり，必要むないのに 括約笳を切除する事はないし，全くその通りである。而 し乍ら, 複雑痔瘦殊に深部広域複雑将瘦にはこれではだ めなのである。

以下この種の手術に対する著者の見解〜反論を述べ る.

1) partial resection と考えられる手術を受けた症 例で，一向に治痖していない症例が屡々認妨られる事.

2）既に炎症侵潤により，その機能を殆ど失っている 外肛門括約筋を温存して一体どの程度の意義ありや.

3）複雑痔瘦，殊に深部広域複雑痔瘦の手術以露天掘 り型式にて開いて行くより外に方法は考えられない。 Partil resection はこの点不満足極りなく; 到定満足な 手術たりえない.

4) 痔緷組織を完全に切り開かずして，どうして主管 を切除〜切り開いたと言いうるのか，一体何を根拠に主 管を処理したと称するか，徹底的に開いてこそはしめて その全貌を把握できる。

5）梁部広域複雑痔瘦にあっては，。再三再四に亘る手 術の繰り返されている事が多く，この種の症例にては徹 底的に切り開いて，始めて原発孔及びそこよりの痔瘦の 進展状態を確認しらるのが普通であり，それでもな㹉 発孔は確認に至らないこともあるほどで，これらを術前 に確認しうるのは神様以外には存在しない：こうした点 で Partial resection は多分に確率による手術であると 評されるも止をを得ない，

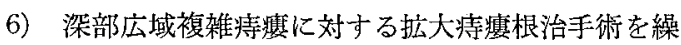
り返し経験した者でないと，即ちこれを Partial resection 及び Colostomy で逃げてばかりいたのでは，こ の種の難物将瘦の満足な触診技術は終生身につかず，往 々にして粘膜のつっぱったもの迄瘦管と誤認する甚だた よりのない触診で事を判断し，全く以て好ましくない.

7) Partial resection はたとえ行なわれるとしても, それは本来の完全な切除に習熟し，その実態を充分に弁 えたものにのみ許さるべきものである.この種の経験な き, 即ち深部広域複雑痔瘦の実熊を満足に知らない者に
許されるべき方法ではない：これでは微積分が分らずに 力学を学ぶのと全く同一である.

8)特瘦のシェーマに欺され好事, 多少とも複雑なもの となると将瘦の図示はその正確な所を伝えるには余りに も不満足でありすぎる。その本来の姿はシェーマで示さ れているものは恐ろしくかけ離れたものである.

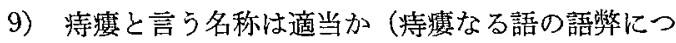
(て)

著者が以前より考えている事であるが，一般に痔瘦， 痔瘦, と簡単に呼称されてはいるが, 痔瘻なる語は往々 にしてその実態とは余りにむかけ離れている。即ち㾌瘦 と言うと，あたかも中空の瘦管が肛門の周囲を這い迴っ ているが如き感をうける。

勿論中にはこの様なものもあり，一本の掼管の単純痔 瘦の如きものも存在する. 而し乍ら将瘦が多少と複雑化 し，それが深部かつ所謂部広域複雑将廔ともなると，そ の実態は往々にして湄管なる概念々は大分異質のもので あり，桪㾇と言う表現は甚だ不適当なむのとなる。

即ち深部広域複雑将瘦にあっては，その肉芽組織が， 括約筋群，殊に外肛門括約筋筋の中に，幾重にも層を為 すが如き形で侵大しており，これが曒痕硬化により，そ の機能を殆ど失い，かつ脆弱化している事が稀ではな 、. 又同様の形で，大既笳内に又これと挙肛筋との閒に 進入し，或いは Lavator ani の表面㐫ちこちら浸潤 し，到底謴管なる概念忙通用しえないのが多い，又この 様な瘦管なる概念よりが離れたものにあっては, 必然 的に瘦管を切開すると言ら概念は通用せず，この種のも のにあっては, 瘦管を切開すると言らょり，むしろ肉芽 組織を切除すると言うべきものでありこの様な点にも 充分な認識を持ち, 複雑冸瘦の手術際しこの瘻管切開の 意味する所を充分に承知しておく必要があると思う。

10) Partial resection で梁部広域複䧴痔瘦が治るな どというのは甚だ軽率である。未だこの力法にて 確実に治るといら証拠はない，完全に切除した訳 でもなく，完全に開いた訳でもない。これをいう ならば30年先の事である。

総じて肛門の手術は，これで良いと言ら事がはっきり するには20年30年と長い年月を要するものである，一時 良い方法ともてはやされても，その後完全に石定される 様な事は往々にしてある。 Whitehead 氏手術などはそ の代表と言いうる. Partital. resection は病巣を完全に 開く訳でもなく，切除する訳でもない.

大体 Partial resection で $100 \%$ 確実に深部広域複雑 痔瘦が治瘾すると言う証拠はどこにもない，観察期間が 短いし，術後の検討にも長期間を必要とする.

痔掼なるものを確実に治す為には，病巣を全部切除す 
るのが最も確実な方法である. 元来 Partial Resection なる方法は，考えようによっては甚だ虫の良すぎる考え 方である. 複雑痔瘦, 殊に深部広域複雑痔瘦にては, 手 術に際して往々以下の二つの反対要因が対立する。

A）痔瘦組織をできうる限り完全に切除したい事.

B）外肛門括約筋をできうる限り損傷したくない事.

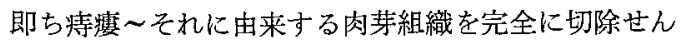
とすれば，外肛門括約筋をあるていど損傷せざるをえず 殊に外肛門括約筋内に肉芽組織が幾重にも層状をなして 侵入している場合には,これを切除するむ止むを得ない。 外肛門括約筋の損傷をさけんとすれば，痔凘組織をみす みすとり残す事になる。

要するに忠ならんと欲すれば孝ならず, 孝ならんと欲 すれば忠ならず，Partial resection はこの相反する二 つの要件を同時に満足せんとする甚だ虫の良い考え方に 基いている. 元来, 深部広域複雑痔㾇を, 全く完全に何 等の障害を残さず，完全に治すと言う事は甚だ無理な注 文であり，不可能である．多少ともその機能を犠牲にし なければ，その満足な治療は計れない，この点早期治療 は甚だ重要である。

総して痔瘦は注じめから複雑痔瘻である梯な事はマズ 殆ど考えられない，はじめは等純痔㿉であり，この時期 に手術をらければ，簡単に治るし，又まず殆ど機能障害 を残さない，これを放置するので，複雑痔瘦に，又深部 広域複雑痔瘦に迄発展し, 我々肛門外科科医が大いに恼 される事になる。従って一般にこうした事を良く認識さ せて㧍く事が何より肝要である。

11）ここ迄言うのは酷であるかもしれないが, Partial resectionによりとり残された雙管から扁平上皮 癌の発生を見る時には何と言って患者に申し立て るか，取り残された病策よりの癌の発生を完全に 否定しらる者はあるまい，

12）複雑痔喽に対する Partial resectionに関して気 惩りな事。

A）複雑痔瘦，殊に深部複雑痔喥の実態を知る者が一 人もなくなってしまう。

B）ただでさえその根治手術に失敗し易い一般外科の 先生方化この様な Partial resection の提唱は, 複雑痔 瘦殊に深部広域複雑痔瘦に詨し, 安易な考光を植えつけ る事になり，その結果:その濫用を招き，益々失敗の率を 高めるものとなりはしないか, 総じて一般の侍膺に対す る考えは甘いもので，これを益々甘いるのとする危惧は ないであろらか，

13）軽々しく Colostomy を提唱すべきでない，全く その必要なき症例に Colostomy の予定されてい る事が往々にしてある，又 Colostomy にて帱瘦
が確実に治るという根拠はない。

14）, 痔瘦は朝顔ではない, 複雑痔瘻, 殊に深部広域複 雑侍瘦にあって，その根と主要な幹をとれば枝葉 は枯れるなどというのは多分に妄説に近く, 将瘦 と朝顔を混同しているに外ならない。

\section{III) 結 論}

要するに Partial resection は詰めの甘い中途半端な 逃げ腰の手術であって, 到底良い手術方法とは考えられ ない，著者は深部広域複雑将瘦の実体を充分に認識すれ ばこの種の手術に賛意を表するものは殆ど消失してし まらであるらと考えている。

擱筆にり，Partial resectionに関する新しい手術方 法の開発に多年に亘り努力を傾倒しておられる好漢, 高 野正博氏の業績を大きく評価し，敬意を表すると共に， 今後の健斗を祈り，その大成を願って止まないるのであ る.

な打本稿は編集の都合上，不本意乍ら，その本来の原 稿及び附図写真を半分以下儿削減し発表するに至ったも のである，著者としては満足にその意をつくす事ができ ず，全く以て遺憾である。詳細㹥文献(15)及び今後の発 表を期待されたい。

\section{文献}

1) Jackman, R. J. 著, 三枝純郎訳：下部結腸疾 患の臨床，医学書院，昭和41年，pp. 188-195.

2) Dathie, H. L.: Progress, Anal Continence. Gut 1971. Vol. 12, pp. 884-852.

3) Preston, G. W. asd Beal J. M. 編集 : Surgical Physiology 1969. Year book Medical Publisher, pp. 283-287.

4) 三枝純郎：肛門外科領域に用いられる下剂の検 討, 一娄便軟化法と関連して一日面肛誌，揭载 予定.

5）幔越莘男・他：肛門病変部位及び痔瘦の新表現 法の提唱, 日值肛誌, Vol. 22, No. 3, pp. 2022 .

6) 三枝純郎：肛阴外科の蹦床, 第 2 版, 永井菖店, 昭和 45 年, pp. 81 .

7）三枝純郎：乳先瘈璂の根治手術，未発表。

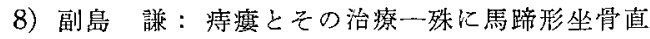

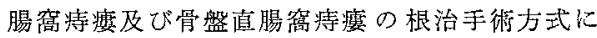
ついて, 日直肛誌, Vol. 25, No. 4, pp. 4 .

9）三枝純郎・他：痔渾と密接な関連の下に発生せ る肚門癌の一例, 外科, Vol. 22, pp. 13441347 , 昭和35年.

10）高野正博 - 他：一時的人工肛門の造設, 閉鎖法, 日直肛誌, Vol. 24, pp. 73 .

11）三枝純郎：排便指尊の三原則一排便機構に関連 して, 日直肛誌，揭載子定.

12）隈越幸男：痔核，痔滨診療の実際，金原出版， 昭和 48 年, pp. 55 . 
13）A. G. Parks，㨍瘦の発生と治療，日本医事新 報，No. 2685，pp. 47，昭和50年.

14) Symposium: Anorectal Problem, Disease of the colon and rectum, Vol. 18, p. 641-669,
J. B. Lippincott, 1975.

15）三枝純郎：深部広域複䧴㾌璂化対方る搪大瘈瘦 根治手術，外科治療，Vol. 34，No. 3， p. 271, 1976. 


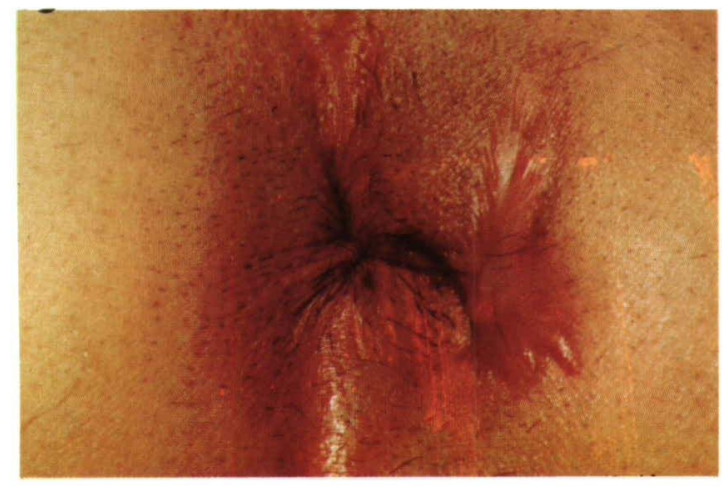

図 1

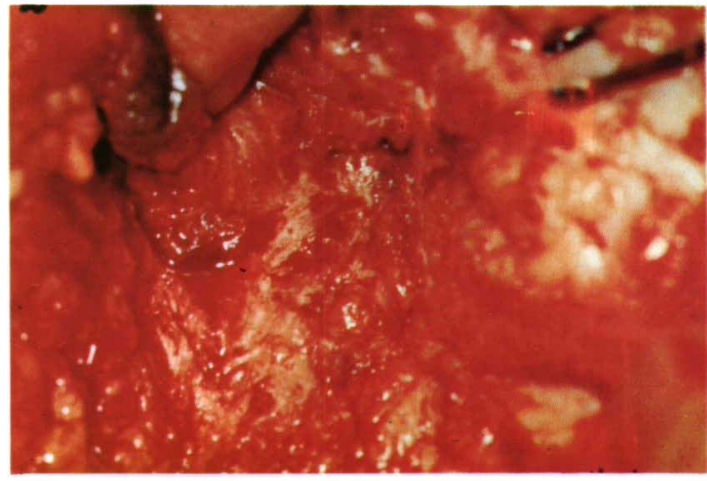

図 2

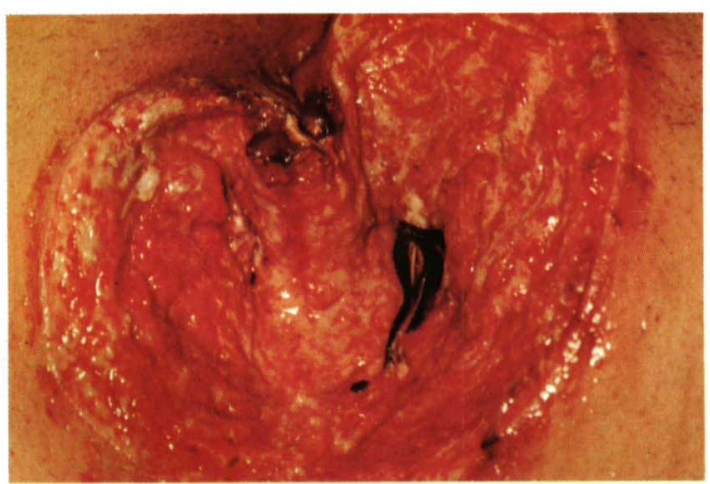

図 3

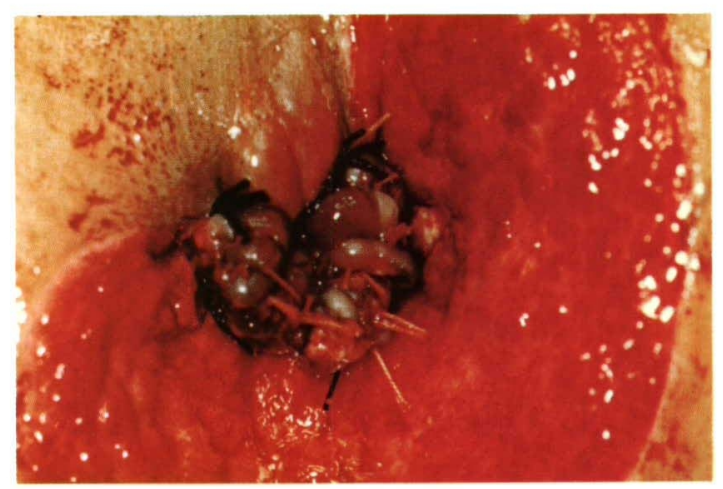

図 4

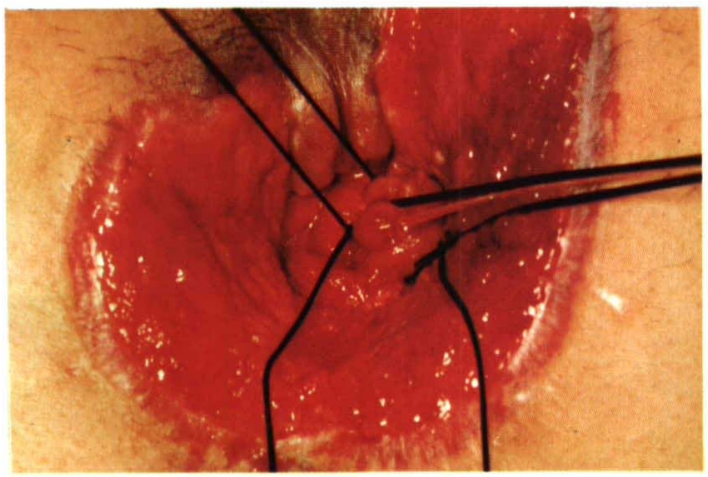

図 5

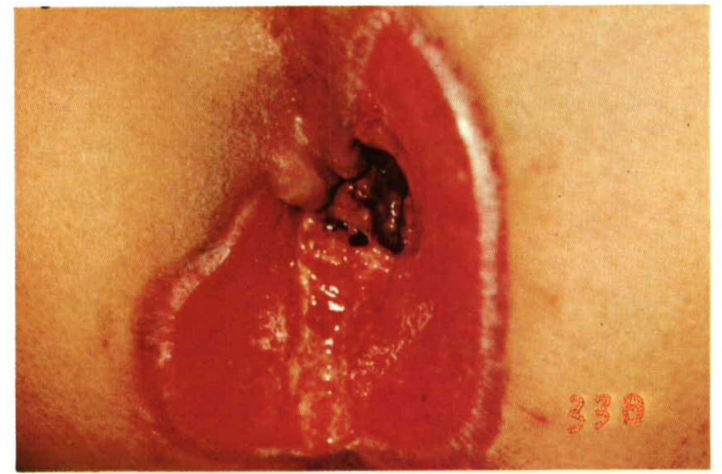

図 6 


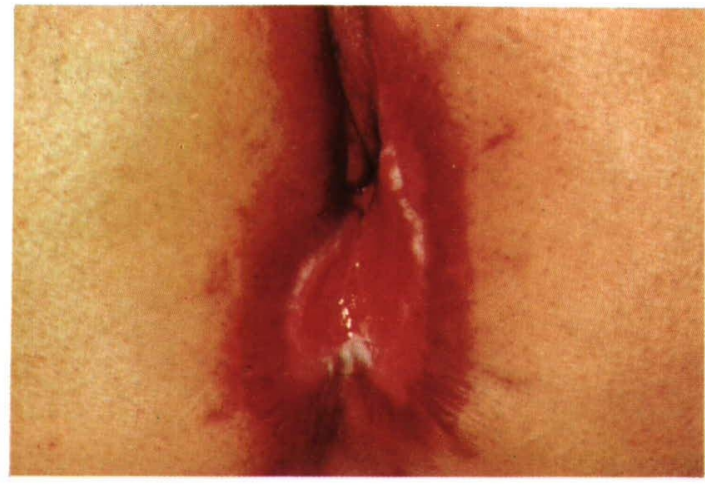

図 7

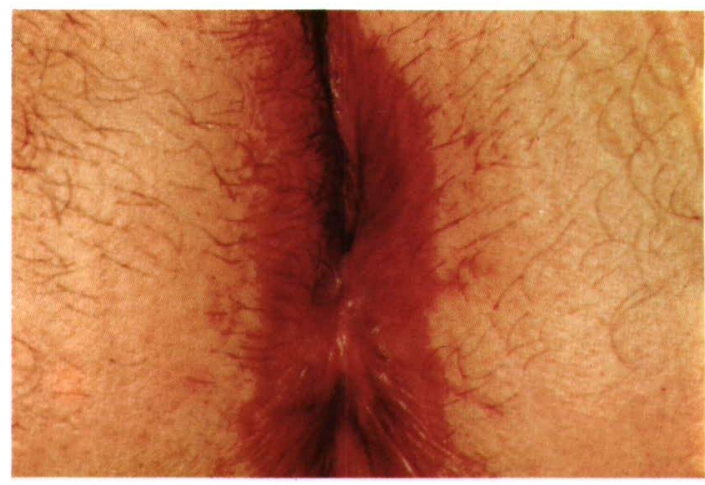

図 8

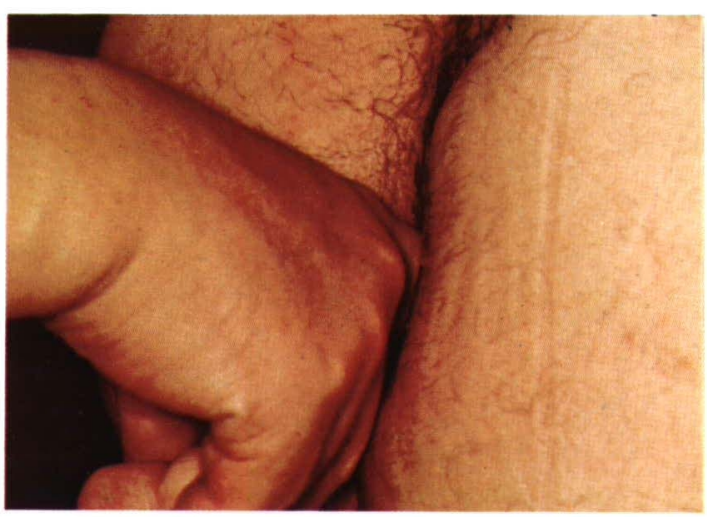

図 9 
図 1

杉 $0 ， 38$ 歳, 静岡市, 肛門亜全切除例

㟝断：深部広域複雑痔战

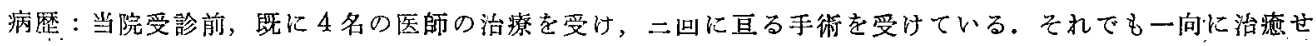
如為，人工肛門の造設が予定されていた，肛門亜全切除実施（2回に分割して手術を行う）。第一回目の手 術にて病巣をすべて開放とし，第二回目の手術にて，肛閒亚全切除街実施，内外肛門括約筋大部分除去、術 式は，亡父三枝俊雄のミシン縫方式による。原発孔は完全に切除〜处理され，又主管上掠ぼしきものも切 除〜処理されているにも拘らず，一向に治瘾しない症例の代表。外㒻上はさほどの症例とは思えないが，内

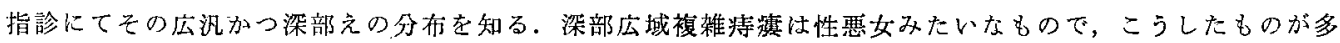
ᄂ.

\section{図 $2 \cdot 3$}

露天堀り形式にて，これをすっかり開いた所見. 桪掼の肉芽組織が底の方に肛門をぐるりと取り巻く様な 形にて沢山残っている。これで治渭しないのも当然である。開いては触診し，触診しては開くここれく

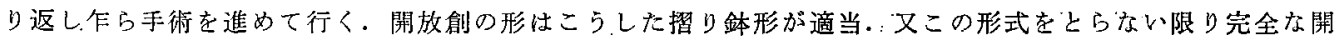

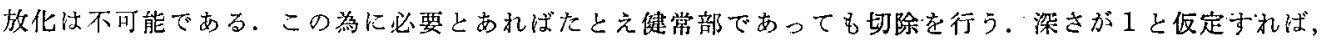

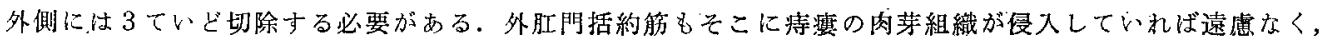
ドンドン切除〜切り開いて行く，出来上った開放手術創は写真19の如く，摺り针状とし；その他の蕒便の貯 溜するが如き形であってはならない。

\section{図 4}

第一回手術後 5 １0日後（余り日を㧍かない方が良い）第二回手術実施. 本症例では第一回手術10日後に 第二回手術が実施された。第一回手術にて，次回にとり除くべく予定された部分を写真の如くミシン縫い形 式にて結帒し，その壊死脱落を計る.

図 5

瀤死部が脱落すると（その脱落後の開放創がこの㥞なスリ鈄形の粪便の流出し易い又その貯溜を招くこと なき良い形になる様に手術すべきである)，肛門はポカンと口をあけを状態になり，次第に粘膜が脱出して 来る。次にこの脱出粘膜を結热し，その壞死脱落を計る。この際，必要に応じては，单に単純結禁のみでな く，針系を用いて 8 の字形にこれを結㷊し，その壊死脱落を計る. 本症例については 3 カ所に 3 回に亘って

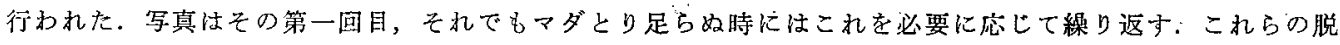
出粘膜をとりまま放置して括くとダブダブの肍門になってしまう由(本文参照)。

图 6

開放創の治瘾期間中に過剩肉泺組織の切除等の開放創の管理をコマメに行う．必要に応じて再三再四行わ

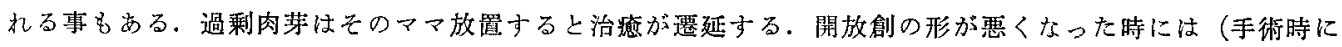
イクラ良い形に切除しても，その治痛経過中に形が昰くなる事は往々にしてある)，必要に応じてその整形 の為に開放創の部分的なケズリを行う．手術創が完全に上皮化する迄，要するにこれを常に粪便物質の貯溜 しない形として招か柇ばならないと言う事である。ブジールングは 5 日に 1 回の制合で行われている。ただ し粘膜絬禁後等の危険の時期は避ける。術後肛門陝窄予防の為の後方切開も必要に応じて行う.

図 7

開放創漸次上皮化に赴く．漸次こ礼が樎少した時に開放創は中に残らず，外に出て来る様に手術を実施し， 又中の方，つまり直腸肛門管内に開放創が残るが如き手術を行うべきではない．総じてこの開放創の粘膜例 の部分は皮虚例の部分にくらべて治洨速度がおそく，この為，前記の如く中 1 外 3 の割合で切除するのであ るが，それでも時として外例の部分が異常に早く上皮化し，中の方に開放㓣が残ってしまう可能性の强い状 態となる事がある。この様な予測の立つ場合には更にその外側の部分をもう一度切除する。中に賃が残ると 往々にして甚だ治瘾遷延する。

完全上皮化前後は甚だコスレ易く，又未だに組織が脆く，帮力なく，この為に大きく破れたりする事があ 
るので泩意を要する。

\section{图 $8 \cdot 9$}

開放創完全上皮化，サイズも丁度良い，而しマダマダ安心できず，開放創完全上皮化を以て植ちに治痖亡

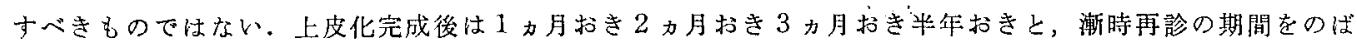

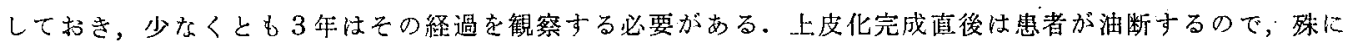
注意を要する，癜痕がコスれたり，タダれたり，時には笔裂して大きく破れてしまう事もあり，上皮化完成 後相当期間をおいて狭窄を生ずる事もある。従ってこの after careの期閒はこれらに関する充分な管理及 び指導を必要とする。熦後 5 年たてばアズ心配はない。

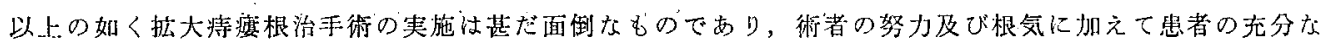
協力がない限り，满足な成果のえら礼ない事は当然である：治療が長期に亘る為，途中で患者の気が变った

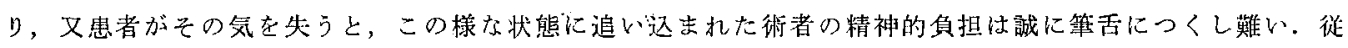
って本法の実施に際しては，術前にこれらの点に関する充分な了解を得て扔く必要がある，安直にひきらけ るべき筋合のものではない，術後の合併症，殊に狭窄の可能性についても理解をむたせ，又必要とあれ杖，

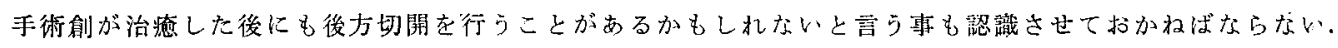

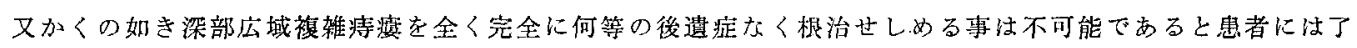
解をえておく方が無難である（実際に怡ど日常坐活に差支えるほどの後道症を認める事はないが）。著者 は手術前これらの点について患者の充分な了解及び同意の得られない限り，その実施を引き受けない事にし ている．患者の中には医師の誠意をふみにじって平然たるむのもある。こうした点をよく見極めた上で，当 方の誠意に対し誠意を以て答える患者に対してのみ本法は笑施されるべきものである: 而し乍らこの判定は 街前には往々にして困難で, 一旦この推定が外れると術者の労苦は水泡に州するのみならず甚だ不快な思に 煩わされる事になる。

加えて应大将港根治手術については，肚門外科の専門医であっても，その認践が甚だ低調であるのが普通

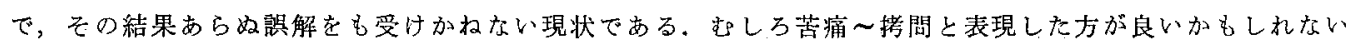
が（尤もこれが本論文執筆の端緒になっているのは事実である.）著者も去年この為に旔だ不快な思いをし た事がある．従ってこうした点も充分に配虑の上で本法は慎重に奏施すべきものである.

な扔深部広域複雑将瘦は女性には稀であるのは不幸中の幸と称すべきであるが、著者は女性の深部広域複

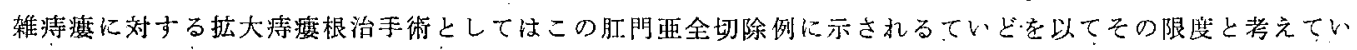
る.出来うればこれも廻避したり、著者の女性の肛門全切除例の経験はこれ迄僅加 1 例であるが, その成果 岋男性のそれに比して甚だ少ったもので西った，女性にあっては胵の存在が大きく留いて来るのは此むを得 ない事である.この点につねては改めて記述する心算りである。 


\title{
Original Articles
}

\section{Studies on the Influential Factors on the Remote Results of Cancer of the Colon and Rectum, Particulary Relation with Stromal Reaction}

\author{
M. Matsuno \\ Second Department of Surgery, Nippon Medical School, Tokyo
}

Recently, remarkable progress has been made on the remote results in the cases operated on colorectal carcinoma, and those participating factors are operation-technique, deeply reaching degree, metastasis to lymphatic nodes and remote metastasis. However, similar to the conventional discussion on benign tumor, there is less report of statistical observation considering the defensive factors in view of the bio-antitumorous nature. We have, therefore, noticed the interstitial reaction at the border-face between the cancer-focus and the normal tissues, namely, the fibrillation and the appearance of the wandering cells, thus we reviewed the remote results of surgical cases on colorectal cartinoma.

In our clinic, 35 caces were surveyed on the relationship between histological findings and prognosis in the patients treated with the operation for colorectal carcinoma in the period from 1959 to 1969 , and we have reviewed the factors which seem to influence on the prognosis by means of our devised diagram-method. As a result, the appearance of the wandering cells was proved to be a very important factor of prognosis.

As the kinds of the wandering cells, we have noticed the nature lymphocytes, neutrocytes, plasma-cells, eosinophilic cells, fibroblasts, monocytes (containing rather big cells with fine cells of round reticular cells, lymphoblasts, and histocytes), as well as mastcells, thus we have reviewed these cell' incidence and distribution.

\section{Extensive and Complete Fistulectomy for Complicated Anorectal Fistula, Especially Total and Subtotal Resection of the Anus as Radical Surgery for the Deep and Wide Spread - Criticising on its Partial Fistulectomy -}

\author{
S. Saigusa \\ 1 Sakae-Cho, Shizuoka City, Shizuoka
}

Total and subtotal resection of the anus as radical surgery for complicated anorectal fistula deep and wide spread all around the anus does not leave so serious complications as 
having been believed. Even if internal and external sphincter are excised completely around the anus, anal function is able to remain without so serious disturbance as long as the surgery is performed following the cardial principle of anorectal surgery being accompanied with proper post operative treatment and after care. But it is quite seldom to encounter such serious case, which needs total resection of the anus. I have only three cases of the total resection among 500 cases of fistula for last 5 years. These result may reveal that puborectal sling is most important factor to keep sphincter continence.

I consider, it is quite difficult to expect its permanent and complete cure by partial fistulectomy resecting only primary opening and main tracts.

\title{
3. The Studies on Experimentally Induced Colonic Carcinoma in Dog by Selective Application of MNNG
}

\author{
H. Onoda \\ First Departmen of Surgery, Toho University School of Medicine, Tokyo
}

There is no report of experimentally developed colon cancer in the dog up to date. In this paper, the experimental high grade atpyical glands of colon in dog which was expected to developed into adenocarcinoma was reported. Administration procedure of MNNG was as follows;

The tip of silicon tube was fixed in the ascending colon through the vermiform appendix and the other end of tube was carried out to the back of the dog through the subcutaneous tunnel. Solution of MNNG with $3 \mathrm{~g} / 1$ tween 60 were injected through this tube twice a week in 8 dogs.

The endoscopic examination were performed regularly in each dog after the start of administration of MNNG. The administration of MNNG were varied depending on the general condition of the dogs.

In one $\operatorname{dog}$ which was underwent of administration of $2 \mathrm{mgMNNG} / \mathrm{kg}$ for weeks and $1 \mathrm{mg} / \mathrm{kg}$ for 41 weeks, the endoscopy demonstrated the lesion similar to IIc+IIa, type of early cancer. Biopsy of the lesion revealed the atypical glands in deep mucosal layer.

By autopsy, this lesion was confirmed as high grade atypical glands and protrusion of its glands into submucosal layer was proved histologically. 